\title{
Rhythmic Technique in Preliteracy of English Language Learning in Increasing Pre-Schoolers Vocabulary
}

\author{
Nor Fazila Bahri, Faridah Yunus \\ Faculty of Education, University Kebangsaan Malaysia, Bangi Selangor, Malaysia \\ Email: faridahyunus@ukm.edu.my,faridahyunus@gmail.com
}

How to cite this paper: Bahri, N. F., \& Yunus, F. (2021). Rhythmic Technique in Preliteracy of English Language Learning in Increasing Pre-Schoolers Vocabulary. Creative Education, 12, 1-20.

https://doi.org/10.4236/ce.2021.121001

Received: November 11, 2020

Accepted: December 28, 2020

Published: December 31, 2020

Copyright $\odot 2021$ by author(s) and Scientific Research Publishing Inc. This work is licensed under the Creative Commons Attribution International License (CC BY 4.0).

http://creativecommons.org/licenses/by/4.0/

\begin{abstract}
English Language adopted the "rhythmic technique" to cultivate and enhance mastery of the second language among preschool children. This rhythmic technique such as jazz chant, nursery rhyme, singing and dancing could broaden the domain of development in the learning and facilitating, or teaching and learning process. In addition, pre-literacy in English Language consisted of four main components relating to children's sensory and auditory skills which are listening, speaking, reading, and writing skills, integrated in this technique. Thirty preschoolers participated in this study who underwent several tests on preliteracy skills after rhythmic techniques were introduced to them. This paper discusses the procedures of intervention method and the scores obtained by the children through five bases or questions (from Q1 to Q5). The results or scores recorded by teachers/researchers on children (K21-K30) show that on average children have improved their skills. These findings are parallel to the previous observations that children tend to master the new vocabulary when emphasis was given to the phrase during rhythmic techniques on induction sets, developments and even plenary. Furthermore, it was hoped that this technique would be a tool for teachers in improving existing teaching processes; for researchers to further enhance the techniques. This study was however limited to the beginning of the implementation and would need further in-depth studies in the future to ensure the optimal growth of English vocabulary mastery in preschools.
\end{abstract}

\section{Keywords}

Pre-Literacy in English Language, Rhythmic Technique, Vocabulary, Preschooler

\section{Introduction}

Today's educational challenges are related to the assessment in preschools that 
require teachers to focus on the $4 \mathrm{M}$ ability (Reading, Writing, Counting, Reasoning). These scores need to be recorded on the documents to monitor children's level of (academic) achievement (Jazira Najua, 2016). As a result, teachers are less able to carry out sensory and concrete activities with the children which are key elements in learning process. The neglected PdPc of English as a second language is affected by the $4 \mathrm{M}$-way-of-mastery-the-subject; and the quality of English is still at an alarming level.

The issue for the study is that pre-school children in this country are still lacking preliteracy skills e.g. vocabulary and letter sound knowledge with the existing $4 \mathrm{M}$ inclined teaching methods. Referring to the renowned experts, musical-based emotions started from childhood with the culture of singing lullaby to the baby to entertain and calm them as well as playing and communicating through singing (Shenfield, Trehub, \& Nakata, 2003; Nakata \& Trehub, 2002). Thus, to empower English as a second language in line with the National Education Development Plan, rhythmic techniques should be emphasized as a method for the mastery of children's language. The current study was carried out to observe the skills performed by young children before and after they have been introduced to several ryhtmic techniques and to record the score as "before-and-after the intervention". It also aims to produce some simple ideas for fellow practitioners who are involved in teaching English, thereby adding value for the pre-school children in Malaysia through some musical and movement techniques (Jawaid, 2014).

\section{Literature Review}

Various national education programs that raised the importance of English as a second language were designed to drive the development of education beginning as early as preschool until the university level (Kementerian Pendidikan Malaysia, 2017). This was because English proficiency among preschool children was still at moderate level based on LINUS (Literacy and Numeracy Screening) study by the Ministry of Education Malaysia (2013). Learning techniques which only focused on academic and emphasized achievement of grades regardless of the diversity of teaching techniques and skills had been unable to stimulate the mind and cognitive development of children (Jazira Najua, 2016). Early childhood education of pre-school or kindergarten should have an impact in generating k-economic growth for high-quality human capital (Trainor \& Cirelli 2015). Therefore, rhythm-based techniques are chosen to be studied by the authors as one of the foundations for later success; it has been found to have positive impact and suitable towards the holistic domain development of children.

Children's minds should be fully stimulated to explore their more active and challenging nature (Nordin \& Norman, 2017). This was in accordance with the Fourth Industrial Revolution in education that emphasized creative nurturing of the children's domains of development using various resources (Buyong \& Othman 2018). Diverse learning techniques could be adopted in PdPc/TLf (Teaching, 
Learning, and Facilitating) to teach children under six years old, especially those that are based on sensory, auditory, and movement such as singing, rhythmic speech, nursery rhymes, jazz chants, role playing, dancing and percussion use (MacNaughton \& Williams, 2009).

In fact, pre-school education for children aged 4 to 6 years has the potential to nourish all aspects of child development including pre-literacy skills by mastering the basic skills of listening, speaking, reading, and writing. This is not just for preparing them to enter the elementary school environment but also to prepare them for world-class education (Yunus 2017). Therefore, a rhythm-based technique was applied in English pre-literacy learning for children in kindergarten, which aimed to enhance the development of children's cognitive, affective, and psychomotor domain, holistically, as well as enhancing their vocabulary (Phoon \& Abdullah 2014).

The LINUS program by KPM was created as an intervention to see the improvement in English KPIs but it was found that parents were inclined to see the mastery of children on only the writing pre-literacy. The existence of this program also resulted in the sole focus of teachers and parents on academic-based learning methods such as examinations and tests (Kosnin et al, 2013). This led to unbalanced growth in children's cognitive domains. Hence the research question was to see the extent of the children's English proficiency, especially from the vocabulary aspect through the application of rhythmic technique in the learning and facilitating in kindergartens.

In fact, the effects of the use of incompatible methods with the concept of child learning development also caused stress to the children. This inhibits the effective and holistic growth and development of the children. Children were not only unable to excellently passed LINUS screenings, but the level of oral proficiency and reading in English at the national level was also unfavorable (KPM, 2017). On the other hand, if the method of singing or rhythmic techniques was used in learning, children were more likely to master the pre-literacy skills easily and successfully (Jazira Najua, 2016).

These music-based emotional responses differed between adults and children; and literacy through music showed a vibrant development beginning as early as pre-school (Hamidin et al. 2017). Therefore, a child should be stimulated by rhythmic techniques to reach the holistic developmental stage at about five years old. Hence, early childhood education expert, Glenda Mac Naughton suggested rhythmic techniques to be used in PdPc especially in improving language and vocabulary. It could also help in four pre-literacy components (LSRW: listening, reading, speaking, writing) among children.

\subsection{Preliteracy English Using Rhythmic Technique}

The four components of the English pre-literacy skills which are listening, speaking, reading, and writing skills need to be combined into the PdPc/TLf process so that the syllabus and learning objectives can be successfully achieved 
(KPM, 2017). Among the goals of pre-literacy in English is to strength the vocabulary, thus the use of rhythm-based techniques is among the advised technique by early childhood expert (MacNaughton \& Williams, 2009). Rhythmic technique in English learning encompasses various musical activities such as singing, movement, percussion, and the earliest in the singing field namely vocal (Rajan, 2013). While singing with lyrics is normally a performance of singing using song lyrics such as nursery rhyme and jazz chant (Connors, 2014).

According to Dalcroze's Theory, the meaning of rhythm in teaching is the rhythm that resulted from the movement, beginning with the natural impulse of human being to move with rhythmic style and dance movements as its source, thereby produced various forms of rhythm and musical structure (Dutton, 2015). Rhythmic techniques covered all activities based on rhythms, sounds, melodies, and movement whether with or without music such as singing, percussion, rhythmic speech, or jazz chant activities (Jones, 2018). English vocabulary is a set of knowledge of words in a language that grows with age and is an effective means of communication in the growth of children in their golden age (Bredekamp, 2014).

Rhythm comes from the vibration; for example, when the table was tapped, the table's surface would move slightly, and the sound would be produced. Similarly, when human make sound or the percussion is blown, the air would vibrate; producing the sound (Strait et al., 2013). The sharper the sound, the higher the pitch and the tension of the vocal cords affects the height of the pitch. Therefore, through these concrete, hands-on experiences the gross and fine motor domain of the children can be enhanced; indirectly so are their adaptive, social, socio-communication and cognitive domains (Horn, 2003) (AEPS). Therefore, the rhythmic techniques in English learning among children can create excitement as the various activities carried out based on the application of rhythm are able to stimulate the ability of children to speak and learn more than 10,000 new vocabulary (Krämer \& Bredekamp 2013).

\subsection{Application of Rhythmic Techniques in Teaching Maintaining the Integrity of the Specifications}

Learning through rhythmic techniques is a friendly and interesting way of attracting children (Franco, Chew, \& Swaine, 2017). Indeed, children are a group of people who love singing and moving (Shenfield, Trehub, \& Nakata, 2011). Therefore, it is easy for the children to understand something especially the lesson through singing activities (Moss, 2019). Creative and innovative methods apply singing, as singing is part of a child's life, which can be integrated while playing or carrying out activities (Lestari \& Ratnaningsih, 2016). However, rhythmic activities need to be made in a simple language style, with short lyrics and tones that are appropriate to the development of children (MacNaughton, \& Willams, 2009). Thus, in this study, the researchers have developed lyrics based on themes (thematic) in English pre-literacy and adapted to the melodies of 
popular children's songs of local culture.

\subsection{Mastery of Vocabulary}

The current study applies singing techniques as a major intervention to identify the level of understanding of pupils; and adapts several instruments such as document analysis, pre-test and post-test and observation forms. The singing technique was chosen because it was well suited to the environment and the pre-school infrastructure, thus activities were carried out with hope that the vocabulary of children would increase gradually. A rhythm-based technique used in English pre-literacy was applied, thereby enhancing vocabulary and English proficiency at preschool level.

Before entering Year One, children who have acquired pre-literacy skills of the second language would understand their environment twice as much as those who did not master them (Bahri \& Yunus, 2018). This difference gap resulted in a huge difference in the amount of vocabulary by the age of five or six years, with average children know about 2500 words, while excellent children could reach up to 5000 - 10,000 words (Moss, 2010). Learning of vocabulary was one of the first steps to learn a second language (Karabulut \& Kesli Dollar, 2016). Nevertheless, the last stage of vocabulary acquisition, both in their own language and in the second language, was rarely achieved because vocabulary procurement was a continuous process. However, there are many theories on acquisition of new vocabulary method/technique based on children's education experts; among them are rhythm-based techniques.

\subsection{The Findings of Noam Chomsky's Theory}

Noam Chomsky stated that the knowledge gained by a child is like a tape recorder on the brain which is a language acquisition device that showed four linguistic features such as the ability of children to distinguish local sounds and other sounds in their surrounding fast, for example listening to the rhythm of music and the sound of an airplane. Children might also describe the linguistic data they hear and like it with various life contexts, for example memorizing the type of job in the form of songs. The linguistic system is easy to adapt to the ability of a child, for example, the ability to create song lyrics based on the vocabulary they learned. Children are also able to continuously evaluate the linguistic system in this globalization through various media around them based on the observation of the sounds (Guignard \& Chomsky, 2011). Therefore, learning the language and mastering vocabulary with rhythmic techniques is appropriate for young children.

\subsection{The Findings of Lev Vygotsky's and Loris Malaguzzi's Theory}

Lev Vygotsky in the zones of proximal development (ZPD), states that the development of children is built based on the existing skills already acquired by them through guidance or known as scaffolding. If the song method is taught to 
the children, then the scaffolding that has been built could holistically improve the child's cognitive and intellectual ability (Holzman, 2013). The ability of children's sensorimotor allow them to master songs and singing. In fact, Reggio Emilia's approach in 100 languages by Loris Malaguzzi also emphasizes the importance of singing the children's natural way of learning. Children would respond naturally to the environment; and the rhythm of life triggered a language phenomenon in children (Bond, 2015). Therefore, the rhythmic techniques are used to improve the children's vocabulary, thus increasing their pre-literacy skills.

\subsection{The Findings of Jean Piaget's Theory}

Jean Piaget stresses that a balance would exist in children when they have a natural tendency to create relationships between what they learn and the situation in their environment (Barrouillet, 2015). Cognitive skills are achieved when children think and develop their minds toward new knowledge and understanding of their experiences. At 3 - 6 years of age, the use of language in children in the pre-operative process occurred pragmatically in different contexts and children could understand the cultural rules when they communicate (Stone, 2012). Children's semantics development would enable them to master 10,000 vocabulary, communicate verbally, understand, and memorize the words of song or poetry (Erneling, 2014). Even in their golden age, children have the capabilities to repeat and modify the song lyrics. This argument reinforces the importance of singing methods to be applied in preliteracy learning.

Children love singing especially if the songs made them feel excited to sing along and dance. The stimulation towards singing is derived from the human nature and it is good to take the opportunity to teach children to sing (Ruksenas, 2012). Children love repetition, so the song could be a great tool to teach a new skill (Welch, 2012). For a more meaningful learning, the use of songs that accompany the images is interesting and this adds to the learning experience. The development of children's motors would also increase with the use of the song as a singing method, especially when dance is involved (Hale et al., 2011). Therefore, singing method is a great way to teach the concept of basic and specific skills. Social skills, behaviors and civilizations could also be taught through the methods of singing (Schwartzberg \& Silverman, 2014). Nursery rhyme is also effective and fun for children and could even be used to teach pre-reading skills.

The diversity of rhythmic techniques is a way to stimulate the interest and aptitude of pre-school students towards learning English to highlight the true potential of children from all aspects of developmental domain from cognitive, socio-communication, social, adaptive, as well as fine and gross motor (Colwell \& Enderson, 2016). It not only enhances the level of English proficiency in pre-school children after the singing method is introduced but could also en- 
hance the ability of pupils to master English language. Rhythm can stimulate and increase English proficiency of children through songs; children would be able to remember and memorize facts quickly (Coople \& Bredekamp, 2009). Before you begin to format your paper, first write and save the content as a separate text file. Keep your text and graphic files separate until after the text has been formatted and styled. Do not use hard tabs, and limit use of hard returns to only one return at the end of a paragraph. Do not add any kind of pagination anywhere in the paper. Do not number text heads, the template will do that for you.

Finally, complete content and organizational editing before formatting. Please take note of the following items when proofreading spelling and grammar:

\section{Research Design}

This study adopted a case study design (Merriam \& Yin 2017) to record the scores of the vocabulary knowledge of young children; to analyze the pattern of scores through a series of tasks/questions. This study was carried out to understand whether rhythmic technique can be a useful tool for children's preliteracy learning or not. It aimed to understand and explore the rhythmic techniques application process in mastering vocabulary among kindergarten children. After these sessions of embedding rhythm into the lessons, children were tested on five levels of skills namely noun, verb, parts of body, rhyming, and personal details.

\subsection{Respondents and Informants}

At the early stage of the study (case study), the purposive sampling was used by researchers on 300 respondents (see Table 1) from 5 kindergartens around Universiti Kebangsaan Malaysia, Bangi. The family income ranged from low to high levels with diverse socio-culture. There were Malays (M), Chinese (C), Indians (I), indigenous people, and Indonesian immigrants (IM). Meanwhile, two female teachers and a male teacher (GT 1-3) who had early childhood education backgrounds and 5 parents (IK 1-5) were willing to cooperate with researchers. To ensure the confidentiality of the informants, all other personal information was kept confidential and codes and nicknames were used.

\subsection{Procedures and Materials}

1) Vocabulary Test

A total of 30 children (see Table 1) underwent the vocabulary test (Vocabulary Test 1) prepared by the researcher, which include oral, reading, and written questions (LSRW) and certified by 3 experts (P1-P3). The questions covered all the themes that the children learned in preschool syllabus (KSPK) that were applied at the national and global level (Dolch Sight Words). There were four baselines according to the vocabulary tested, including nouns, verbs, alphabetical sound/rhyming words, parts of the body and personal details. The intervention in the form of rhythmic technique was carried out during children's learning. 
Table 1. Demographics profile of children at kindergarten.

\begin{tabular}{|c|c|c|c|c|c|}
\hline $\begin{array}{l}\text { Name of children } \\
\qquad(\mathbf{k} 1-\mathrm{K} 30)\end{array}$ & Gender & Race & $\begin{array}{c}\text { Age } \\
\text { (at } 1 / 1)\end{array}$ & $\begin{array}{l}\text { Parent's income } \\
\text { b40/m } 40 / \mathrm{t} 20\end{array}$ & $\begin{array}{c}\text { Kindergarden } \\
\text { location } \mathrm{pb} / \mathrm{db} / \mathrm{lb}\end{array}$ \\
\hline K1 & $\mathrm{L}$ & M & 5.3 & M40 & PB \\
\hline K2 & $\mathrm{L}$ & M & 5.7 & M40 & PB \\
\hline K3 & $\mathrm{L}$ & $\mathrm{M}$ & 5.0 & M40 & PB \\
\hline K4 & $\mathrm{L}$ & M & 5.5 & M40 & PB \\
\hline K5 & $\mathrm{L}$ & $\mathrm{M}$ & 5.5 & M40 & PB \\
\hline K6 & $\mathrm{L}$ & $\mathrm{M}$ & 4.11 & M40 & PB \\
\hline K7 & $\mathrm{P}$ & M & 5.0 & M40 & PB \\
\hline K8 & $\mathrm{P}$ & $\mathrm{M}$ & 5.6 & M40 & PB \\
\hline K9 & $\mathrm{P}$ & $\mathrm{C}$ & 5.2 & T20 & $\mathrm{PB}$ \\
\hline K10 & $\mathrm{P}$ & I & 4.5 & $\mathrm{~T} 20$ & DB \\
\hline K11 & $\mathrm{L}$ & $\mathrm{C}$ & 5.0 & $\mathrm{~T} 20$ & DB \\
\hline K12 & $\mathrm{P}$ & M & 5.4 & M40 & DB \\
\hline K13 & $\mathrm{P}$ & $\mathrm{M}$ & 5.3 & M40 & DB \\
\hline K14 & $\mathrm{P}$ & $\mathrm{M}$ & 5.4 & M40 & DB \\
\hline K15 & $\mathrm{P}$ & IM & 5.7 & M40 & DB \\
\hline K16 & $\mathrm{L}$ & IM & 5.4 & B40 & DB \\
\hline K17 & $\mathrm{L}$ & $\mathrm{M}$ & 5.1 & M40 & DB \\
\hline K18 & $\mathrm{L}$ & $\mathrm{M}$ & 5.9 & M40 & $\mathrm{DB}$ \\
\hline K19 & $\mathrm{P}$ & $\mathrm{M}$ & 4.3 & M40 & DB \\
\hline K20 & $\mathrm{L}$ & M & 5.1 & T20 & DB \\
\hline K21 & $\mathrm{P}$ & $\mathrm{M}$ & 5.5 & $\mathrm{~T} 20$ & $\mathrm{LB}$ \\
\hline K22 & $\mathrm{L}$ & M & 5.6 & M40 & $\mathrm{LB}$ \\
\hline K23 & $\mathrm{L}$ & M & 5.10 & M40 & LB \\
\hline K24 & $\mathrm{P}$ & $\mathrm{M}$ & 5.9 & M40 & LB \\
\hline K25 & $\mathrm{P}$ & $\mathrm{M}$ & 5.5 & M40 & LB \\
\hline K26 & $\mathrm{P}$ & M & 5.7 & M40 & LB \\
\hline K27 & $\mathrm{P}$ & $\mathrm{M}$ & 5.0 & M40 & LB \\
\hline K28 & $\mathrm{L}$ & $\mathrm{M}$ & 5.4 & M40 & LB \\
\hline K29 & $\mathrm{L}$ & $\mathrm{M}$ & 5.5 & M40 & LB \\
\hline K30 & $\mathrm{L}$ & $\mathrm{M}$ & 4.7 & T20 & LB \\
\hline
\end{tabular}

2) Observations of Teaching and Learning Process

Periodic observations were carried out during intervention which aim was to increase the vocabulary of children. Pictures and audio learning about rhythmic techniques were recorded; data collection on the actual study was conducted for three months beginning in August, September and ending in October. The rationale for conducting studies beginning in the second term was to study the improvement of vocabulary since children had already gone through basic learning of English. Researchers used various forms of rhythmic activities such as jazz chant, nursery rhyme, skeleton dance and singing. 


\section{Data Analysis}

The research data was based on the intervention test of vocabulary items conducted on 30 children (K1 - K30) expressed through baseline analysis. It was analyzed in descriptive tables of item scores for each vocabulary tested. From the observations, children were exposed to movements and dances (skeleton dance) that allowed them to identify limbs using the gross and fine motor. In the phrase "shake your hand to the left/right", it showed that rhythmic techniques formed the appropriate vocabulary for children. The following paragraphs explain the five bases and the scores.

\subsection{Baseline 1: Nouns (Listening \& Speaking Skill)}

Question No.1 (Q1): "Listen to your teacher"; as teacher shows picture of a cat, see (Figure 1) and "Name the animals as you look at the pictures carefully". Sample answers from children: "I have a cat"; "My cat is black".

From the analysis of item score (shown in Table 2) for baseline/question 1 , the average score was 0.8 . It was found that $100 \%$ children could mention S1 (cat), S8 (black) and S10 (car). The results showed that the children learned jazz chant techniques that emphasized the tested vocabulary.

\subsection{Baseline 2: Verbs (Listening \& Speaking)}

The rhythmic method observed in class routines such as movement using verbs enhanced children's vocabulary on verbs mentioned above. When teacher asked children to do according to the verbs in Table 3; scores were recorded as to disqualify who had not perform correctly. Words like sit, eat, and jump are very easily understood by the children generally, however, 'take' may need more practice.

\subsection{Baseline 3: Parts of the Body (Speaking \& Reading)}

Teachers randomly tested 10 words (word cards) indicated on limbs (see Figure 2 ) and the children would pronounce the word and attached the word card to the correct place. Table 4 shows the scores obtained by the children. The word "eye" needs no more attention however, "knee" and "head" seem to be a problem. More research needs to be carried out in the future to understand further the reason for such phenomena.

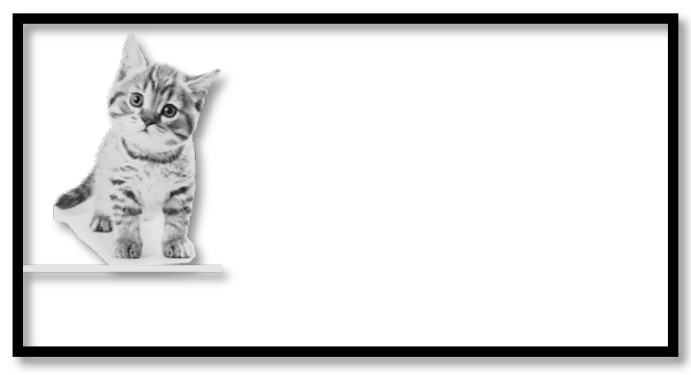

Figure 1. Sample of picture for Q1. 
Table 2. Item score for Q1.

\begin{tabular}{|c|c|c|c|c|c|c|c|c|c|c|c|}
\hline Q/Child & $\begin{array}{l}\text { S1 } \\
\text { cat }\end{array}$ & $\begin{array}{c}S 2 \\
\text { rabbit }\end{array}$ & $\begin{array}{c}\text { S3 } \\
\text { bird }\end{array}$ & $\begin{array}{c}\text { S4 } \\
\text { horse }\end{array}$ & $\begin{array}{c}\text { S5 } \\
\text { hen }\end{array}$ & $\begin{array}{l}\text { S6 } \\
\text { red }\end{array}$ & $\begin{array}{c}\text { S7 } \\
\text { blue }\end{array}$ & $\begin{array}{c}\text { S8 } \\
\text { black }\end{array}$ & $\begin{array}{c}\text { S9 } \\
\text { doll }\end{array}$ & $\begin{array}{l}\text { S10 } \\
\text { car }\end{array}$ & score $/ 10$ \\
\hline$K 1$ & I & I & I & I & - & I & - & I & - & I & 0.7 \\
\hline$K 2$ & I & I & I & I & I & I & I & I & 1 & I & 1.0 \\
\hline$K 3$ & I & I & I & I & I & I & I & I & 1 & I & 1.0 \\
\hline$K 4$ & I & I & I & I & - & I & I & I & - & I & 0.8 \\
\hline$K 5$ & I & I & I & 1 & - & I & I & I & - & I & 0.9 \\
\hline$K 6$ & I & I & I & I & I & I & 1 & I & I & I & 1.0 \\
\hline$K 7$ & I & I & I & I & I & I & I & I & I & I & 1.0 \\
\hline$K 8$ & I & & & I & - & - & I & I & - & I & 0.7 \\
\hline$K 9$ & I & I & I & I & I & I & I & I & I & I & 1.0 \\
\hline$K 10$ & I & I & I & 1 & - & 1 & I & I & I & I & 0.9 \\
\hline$K 11$ & I & I & I & 1 & I & 1 & I & I & I & I & 1.0 \\
\hline$K 12$ & I & 1 & 1 & I & - & I & I & 1 & I & I & 0.9 \\
\hline$K 13$ & I & I & I & 1 & - & I & I & I & I & I & 0.9 \\
\hline$K 14$ & I & I & I & 1 & I & 1 & I & 1 & I & 1 & 1.0 \\
\hline K15 & 1 & I & 1 & 1 & I & 1 & I & 1 & I & I & 1.0 \\
\hline K16 & 1 & I & 1 & 1 & - & 1 & I & 1 & - & I & 0.8 \\
\hline$K 17$ & 1 & I & 1 & 1 & I & 1 & 1 & 1 & 1 & 1 & 0.9 \\
\hline$K 18$ & I & 1 & I & 1 & - & I & I & I & 1 & I & 0.9 \\
\hline$K 19$ & I & 1 & 1 & 1 & 1 & 1 & 1 & I & I & I & 1.0 \\
\hline$K 20$ & 1 & 1 & 1 & 1 & I & 1 & I & 1 & 1 & I & 1.0 \\
\hline$K 21$ & 1 & - & - & 1 & - & - & - & 1 & - & I & 0.4 \\
\hline$K 22$ & 1 & 1 & 1 & 1 & I & 1 & I & 1 & 1 & I & 1.0 \\
\hline$K 23$ & 1 & I & I & 1 & I & 1 & I & 1 & I & I & 1.0 \\
\hline$K 24$ & 1 & - & 1 & - & - & I & - & 1 & - & I & 0.5 \\
\hline$K 25$ & 1 & - & 1 & 1 & 1 & 1 & - & 1 & 1 & I & 0.7 \\
\hline$K 26$ & 1 & I & 1 & 1 & 1 & 1 & I & 1 & 1 & I & 1.0 \\
\hline$K 27$ & 1 & 1 & 1 & 1 & 1 & 1 & 1 & 1 & I & I & 1.0 \\
\hline$K 28$ & 1 & & I & 1 & & & I & 1 & & I & 0.5 \\
\hline$K 29$ & 1 & I & 1 & 1 & 1 & I & I & I & 1 & I & 1.0 \\
\hline \multirow[t]{2}{*}{$K 30$} & 1 & 1 & I & 1 & 1 & I & I & 1 & 1 & I & 1.0 \\
\hline & 30 & 25 & 28 & 29 & 17 & 27 & 26 & 30 & 22 & 30 & \\
\hline
\end{tabular}


Table 3. Descriptive analysis of items score for Q2.

\begin{tabular}{|c|c|c|c|c|c|c|c|c|c|c|c|}
\hline $\begin{array}{c}\text { Q/ } \\
\text { Child }\end{array}$ & $\begin{array}{c}S 1 \\
\text { play }\end{array}$ & $\begin{array}{c}S 2 \\
\text { sing }\end{array}$ & $\begin{array}{c}S 3 \\
j u m p\end{array}$ & $\begin{array}{l}S 4 \\
\text { sit }\end{array}$ & $\begin{array}{c}S 5 \\
\text { run }\end{array}$ & $\begin{array}{c}S 6 \\
\text { take }\end{array}$ & $\begin{array}{c}S 7 \\
\text { stand }\end{array}$ & $\begin{array}{l}S 8 \\
\text { eat }\end{array}$ & $\begin{array}{c}S 9 \\
\text { drink }\end{array}$ & $\begin{array}{l}S 10 \\
\text { give }\end{array}$ & $\begin{array}{c}\text { score } \\
10\end{array}$ \\
\hline K1 & 1 & 1 & I & 1 & - & - & - & 1 & - & - & 0.5 \\
\hline K2 & 1 & 1 & 1 & I & I & - & I & 1 & 1 & 1 & 0.9 \\
\hline K3 & 1 & 1 & I & I & 1 & 1 & I & 1 & 1 & 1 & 1.0 \\
\hline K4 & I & 1 & I & I & - & I & I & 1 & - & I & 0.8 \\
\hline K5 & 1 & 1 & 1 & 1 & - & 1 & I & 1 & - & 1 & 0.8 \\
\hline K6 & 1 & 1 & 1 & 1 & 1 & 1 & 1 & 1 & 1 & 1 & 1.0 \\
\hline K7 & 1 & 1 & 1 & 1 & 1 & - & I & 1 & I & 1 & 0.9 \\
\hline K8 & I & - & - & I & - & - & 1 & 1 & - & 1 & 0.5 \\
\hline K9 & I & 1 & 1 & I & 1 & - & I & 1 & 1 & 1 & 0.9 \\
\hline K10 & I & 1 & 1 & I & - & I & I & 1 & I & 1 & 0.9 \\
\hline K11 & 1 & 1 & I & 1 & 1 & 1 & I & 1 & 1 & 1 & 1.0 \\
\hline K12 & 1 & 1 & 1 & I & - & 1 & I & 1 & 1 & 1 & 0.9 \\
\hline K13 & 1 & 1 & I & I & - & 1 & I & 1 & 1 & 1 & 0.9 \\
\hline K14 & 1 & 1 & 1 & I & 1 & 1 & I & 1 & I & 1 & 1.0 \\
\hline K15 & I & 1 & 1 & I & 1 & I & I & 1 & I & I & 1.0 \\
\hline K16 & I & 1 & 1 & I & - & 1 & 1 & 1 & - & I & 0.8 \\
\hline K17 & I & 1 & I & I & I & I & I & 1 & I & I & 1.0 \\
\hline K18 & 1 & 1 & 1 & I & - & 1 & I & 1 & 1 & 1 & 0.9 \\
\hline K19 & 1 & 1 & 1 & 1 & I & - & I & 1 & 1 & 1 & 0.9 \\
\hline K20 & I & 1 & I & I & 1 & 1 & I & 1 & I & I & 1.0 \\
\hline K21 & I & - & - & I & - & - & - & 1 & - & - & 0.3 \\
\hline K22 & 1 & 1 & 1 & I & 1 & - & 1 & 1 & 1 & 1 & 0.9 \\
\hline K23 & I & 1 & 1 & I & 1 & - & I & 1 & I & I & 0.9 \\
\hline K24 & - & - & I & - & - & - & I & 1 & - & - & 0.3 \\
\hline K25 & I & - & 1 & I & 1 & I & - & 1 & I & I & 0.8 \\
\hline K26 & - & 1 & 1 & I & I & I & - & 1 & 1 & - & 0.7 \\
\hline K27 & 1 & I & I & I & I & 1 & I & 1 & 1 & 1 & 1.0 \\
\hline K28 & I & - & 1 & I & - & - & - & 1 & - & 1 & 0.6 \\
\hline K29 & I & 1 & I & I & I & - & - & 1 & 1 & - & 0.7 \\
\hline \multirow[t]{2}{*}{ K30 } & 1 & I & I & 1 & I & 1 & 1 & 1 & 1 & 1 & 1.0 \\
\hline & 28 & 25 & 28 & 29 & 18 & 18 & 24 & 30 & 22 & 25 & \\
\hline
\end{tabular}




\subsection{Baseline 4: Rhyming Words (LSRW)}

In this phase, teacher asks children to circle the word as shown in Figure 3 that does not belong to the same sound; scores can be seen in Table 5. The words "man" and "can", "rain"/"train" seem to have low scores overall. This mistake could be due to confusion of sound/words from the original language.

Some experts and practitioners assume that rhythmic techniques must be applied alongside phonics method to master the sound of the word. The phonetic/phonic method is for recognizing sounds in a language, in which English had 44 sounds that contained 190 graphemes. Many previous studies showed that phonic method was very effective for children with low cognitive achievement and for the beginners in pre-literacy of reading. Phonics is used in rhythmic techniques such as singing alphabets and sound to make them more understandable and memorable.

Many words have same rhythmic sound at the end or at the beginning of the word; in the form of rhyme verse, the sound of the rhyme was the same at the end of each row, for example/cat/, /bat///mat/ended with the letter/at/at the end of the word. However, in terms of rime or rhyme, it was different (Rabindra Dev

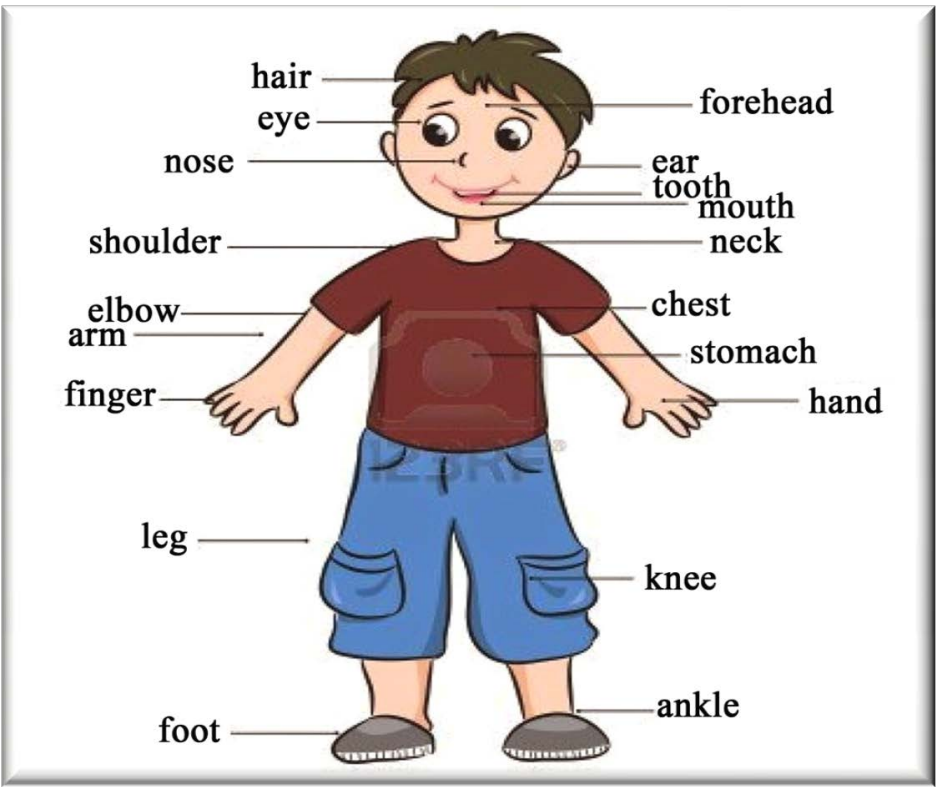

Figure 2. Sample of Question No 3.
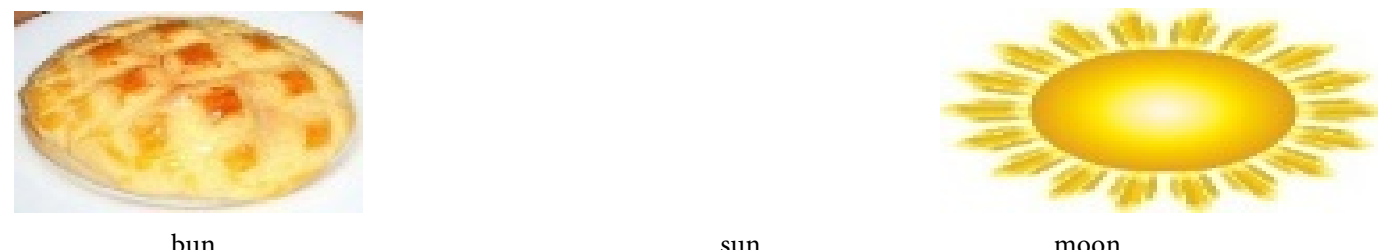

Figure 3. Sample of Question No 4. 
Table 4. Descriptive Analysis of Items Score for Q3.

\begin{tabular}{|c|c|c|c|c|c|c|c|c|c|c|c|}
\hline Q/Child & $\begin{array}{l}\text { W1 } \\
\text { eye }\end{array}$ & $\begin{array}{l}\text { W2 } \\
\text { ear }\end{array}$ & $\begin{array}{c}\text { W3 } \\
\text { nose }\end{array}$ & $\begin{array}{c}\text { W4 } \\
\text { mouth }\end{array}$ & $\begin{array}{l}\text { W5 } \\
\text { head }\end{array}$ & $\begin{array}{l}\text { W6 } \\
\text { hand }\end{array}$ & $\begin{array}{l}\text { W7 } \\
\text { leg }\end{array}$ & $\begin{array}{l}\text { W8 } \\
\text { hair }\end{array}$ & $\begin{array}{l}\text { W9 } \\
\text { teeth }\end{array}$ & $\begin{array}{l}\text { W10 } \\
\text { knee }\end{array}$ & $\begin{array}{c}\text { score } \\
10\end{array}$ \\
\hline K1 & I & 1 & I & I & 1 & I & - & 1 & - & - & 0.7 \\
\hline K2 & I & 1 & 1 & I & 1 & I & I & 1 & I & I & 1.0 \\
\hline K3 & 1 & 1 & 1 & 1 & 1 & 1 & I & 1 & 1 & I & 1.0 \\
\hline K4 & 1 & 1 & 1 & 1 & - & 1 & I & 1 & - & - & 0.7 \\
\hline K5 & 1 & 1 & 1 & I & - & 1 & I & 1 & - & - & 0.7 \\
\hline K6 & 1 & 1 & 1 & I & 1 & 1 & 1 & 1 & 1 & 1 & 1.0 \\
\hline K7 & I & 1 & 1 & I & 1 & 1 & I & 1 & 1 & 1 & 1.0 \\
\hline K8 & 1 & - & - & I & - & - & I & 1 & - & - & 0.3 \\
\hline K9 & I & I & 1 & I & I & 1 & I & 1 & 1 & 1 & 1.0 \\
\hline K10 & 1 & I & 1 & I & - & I & 1 & I & 1 & I & 0.9 \\
\hline K11 & 1 & 1 & 1 & I & I & 1 & I & 1 & 1 & I & 1.0 \\
\hline K12 & I & 1 & 1 & I & - & 1 & 1 & 1 & 1 & 1 & 0.9 \\
\hline K13 & I & 1 & I & I & - & 1 & I & 1 & I & I & 0.9 \\
\hline K14 & 1 & 1 & 1 & 1 & I & 1 & I & 1 & 1 & 1 & 1.0 \\
\hline K15 & 1 & I & 1 & I & I & 1 & I & 1 & 1 & 1 & 1.0 \\
\hline K16 & I & 1 & 1 & I & - & 1 & 1 & 1 & - & I & 0.8 \\
\hline K17 & I & I & 1 & I & I & 1 & I & 1 & 1 & I & 1.0 \\
\hline K18 & I & I & 1 & I & - & 1 & I & 1 & 1 & 1 & 0.9 \\
\hline K19 & 1 & 1 & I & I & 1 & I & I & 1 & I & I & 1.0 \\
\hline K20 & I & I & 1 & I & I & 1 & I & 1 & 1 & 1 & 1.0 \\
\hline K21 & 1 & - & - & I & - & - & - & 1 & - & - & 0.3 \\
\hline K22 & 1 & 1 & 1 & 1 & I & 1 & I & 1 & 1 & 1 & 1.0 \\
\hline K23 & I & I & 1 & I & I & 1 & 1 & 1 & 1 & 1 & 1.0 \\
\hline K24 & I & - & 1 & - & - & 1 & - & 1 & - & - & 0.4 \\
\hline K25 & I & - & 1 & I & I & 1 & - & 1 & 1 & I & 0.8 \\
\hline K26 & 1 & I & 1 & I & I & I & I & 1 & I & 1 & 1.0 \\
\hline K27 & 1 & I & 1 & I & I & 1 & I & 1 & 1 & 1 & 1.0 \\
\hline K28 & I & - & 1 & I & - & - & I & 1 & - & - & 0.5 \\
\hline K29 & I & I & 1 & I & 1 & 1 & I & 1 & 1 & I & 1.0 \\
\hline \multirow[t]{2}{*}{ K30 } & I & 1 & 1 & 1 & 1 & 1 & I & 1 & 1 & 1 & 1.0 \\
\hline & 30 & 25 & 28 & 29 & 19 & 27 & 26 & 30 & 26 & 23 & \\
\hline
\end{tabular}


Table 5. Descriptive analysis of items score for Q4.

\begin{tabular}{|c|c|c|c|c|c|c|c|c|c|c|c|}
\hline $\begin{array}{c}\text { Q/ } \\
\text { Child }\end{array}$ & $\begin{array}{l}\text { S1 } \\
\text { bun } \\
\text { sun }\end{array}$ & $\begin{array}{l}\text { S2 } \\
\text { cat } \\
\text { rat }\end{array}$ & $\begin{array}{c}\text { S3 } \\
\text { tree } \\
\text { three }\end{array}$ & $\begin{array}{l}\text { S4 } \\
\text { pin } \\
\text { tin }\end{array}$ & $\begin{array}{c}\text { S5 } \\
\text { man } \\
\text { can }\end{array}$ & $\begin{array}{c}\text { S6 } \\
\text { bed } \\
\text { red }\end{array}$ & $\begin{array}{c}\text { S7 } \\
\text { blue } \\
\text { glue }\end{array}$ & $\begin{array}{c}\text { S8 } \\
\text { nail } \\
\text { pail }\end{array}$ & $\begin{array}{c}\text { S9 } \\
\text { rain } \\
\text { train }\end{array}$ & $\begin{array}{l}\text { S10 } \\
\text { car } \\
\text { jar }\end{array}$ & $\begin{array}{c}\text { score } \\
/ 10\end{array}$ \\
\hline$K 1$ & - & I & I & I & - & I & - & I & - & I & 0.6 \\
\hline$K 2$ & I & I & I & I & I & I & I & I & I & I & 1.0 \\
\hline$K 3$ & I & I & I & I & I & I & I & I & I & I & 1.0 \\
\hline$K 4$ & I & I & I & I & - & 1 & 1 & I & - & I & 0.8 \\
\hline$K 5$ & I & I & I & I & - & I & I & I & - & I & 0.8 \\
\hline K6 & I & I & I & I & I & I & I & I & 1 & I & 1.0 \\
\hline$K 7$ & - & I & I & I & 1 & 1 & I & I & I & 1 & 0.9 \\
\hline$K 8$ & - & I & - & 1 & - & - & 1 & I & - & 1 & 0.5 \\
\hline$K 9$ & I & I & I & I & I & I & I & I & I & I & 1.0 \\
\hline$K 10$ & I & I & I & I & - & I & I & I & I & I & 0.9 \\
\hline$K 11$ & I & I & I & I & I & 1 & 1 & I & I & I & 1.0 \\
\hline$K 12$ & I & I & I & I & - & I & I & I & I & I & 0.9 \\
\hline$K 13$ & I & I & I & I & - & I & I & I & I & I & 1.0 \\
\hline$K 14$ & I & I & I & I & I & I & I & I & I & I & 1.0 \\
\hline$K 15$ & I & I & I & I & I & 1 & I & I & I & I & 1.0 \\
\hline$K 16$ & I & I & I & I & - & I & I & I & - & I & 0.8 \\
\hline$K 17$ & I & I & I & I & I & I & I & I & I & I & 1.0 \\
\hline$K 18$ & I & I & I & I & - & 1 & I & I & I & I & 0.9 \\
\hline$K 19$ & I & I & I & I & I & 1 & 1 & I & I & I & 1.0 \\
\hline$K 20$ & I & I & I & I & I & I & 1 & I & I & I & 1.0 \\
\hline$K 21$ & I & - & - & I & - & - & - & I & - & - & 0.3 \\
\hline$K 22$ & I & I & I & 1 & I & 1 & I & I & I & I & 1.0 \\
\hline$K 23$ & I & I & I & 1 & 1 & 1 & I & I & I & I & 1.0 \\
\hline$K 24$ & I & - & I & - & - & I & - & I & - & - & 0.4 \\
\hline$K 25$ & - & - & I & I & I & I & - & I & I & I & 0.7 \\
\hline$K 26$ & I & I & I & I & 1 & 1 & 1 & I & I & I & 1.0 \\
\hline$K 27$ & I & I & I & I & I & 1 & 1 & I & I & I & 1.0 \\
\hline$K 28$ & 1 & - & I & 1 & - & - & I & I & - & - & 0.5 \\
\hline$K 29$ & I & I & I & I & I & I & I & I & I & 1 & 1.0 \\
\hline \multirow[t]{2}{*}{$K 30$} & I & I & I & 1 & I & I & I & I & I & 1 & 1.0 \\
\hline & 26 & 26 & 28 & 29 & 18 & 27 & 26 & 30 & 22 & 27 & \\
\hline
\end{tabular}


Table 6. Descriptive analysis of items score for Q5.

\begin{tabular}{|c|c|c|c|c|c|c|}
\hline $\begin{array}{c}\text { Q/ } \\
\text { Child }\end{array}$ & $\begin{array}{c}\text { S1 } \\
(\text { My name is...) }\end{array}$ & $\begin{array}{c}\text { S2 } \\
\text { (I am five...) }\end{array}$ & $\begin{array}{c}\text { S3 } \\
(\text { I live in...) }\end{array}$ & $\begin{array}{c}\text { S4 } \\
\text { (I am a boy/girl) }\end{array}$ & $\begin{array}{c}\text { S5 } \\
\text { (I am fine...) }\end{array}$ & $\begin{array}{l}\text { score } \\
(\mathrm{sx} 2)\end{array}$ \\
\hline$K 1$ & I & I & I & I & I & 0.5 \\
\hline$K 2$ & I & I & I & I & I & 0.5 \\
\hline$K 3$ & I & I & I & $I$ & I & 0.5 \\
\hline$K 4$ & I & I & I & I & - & 0.4 \\
\hline$K 5$ & I & I & I & I & - & 0.8 \\
\hline K6 & I & I & I & I & I & 1.0 \\
\hline$K 7$ & I & I & I & I & I & 1.0 \\
\hline$K 8$ & I & - & - & $I$ & - & 0.4 \\
\hline$K 9$ & I & I & I & I & I & 1.0 \\
\hline$K 10$ & I & I & I & I & - & 0.8 \\
\hline$K 11$ & I & I & I & I & I & 1.0 \\
\hline$K 12$ & I & I & I & I & - & 0.8 \\
\hline$K 13$ & I & I & I & I & - & 1.0 \\
\hline$K 14$ & I & I & I & I & I & 1.0 \\
\hline$K 15$ & I & I & I & I & I & 1.0 \\
\hline K16 & I & I & I & I & - & 0.8 \\
\hline$K 17$ & I & I & I & I & I & 1.0 \\
\hline$K 18$ & I & I & I & I & - & 0.8 \\
\hline$K 19$ & I & I & I & I & I & 1.0 \\
\hline$K 20$ & I & I & I & I & I & 1.0 \\
\hline$K 21$ & I & - & - & I & - & 0.4 \\
\hline$K 22$ & I & I & I & I & I & 1.0 \\
\hline$K 23$ & I & I & I & I & I & 1.0 \\
\hline$K 24$ & I & - & - & I & - & 0.4 \\
\hline$K 25$ & I & - & I & I & I & 0.8 \\
\hline$K 26$ & I & I & I & I & I & 1.0 \\
\hline$K 27$ & I & I & I & I & I & 1.0 \\
\hline$K 28$ & I & I & I & I & I & 1.0 \\
\hline$K 29$ & I & I & I & I & I & 1.0 \\
\hline \multirow[t]{2}{*}{ K30 } & I & I & I & I & I & 1.0 \\
\hline & 30 & 26 & 27 & 30 & 20 & \\
\hline
\end{tabular}

Prasad 2016), for example, the rhythm sounds for "main" and "mane". The rhythm sounds were the same but from different rhyme, as follows:

"rain, pain, train, chain" from the rhyme family "ain"

"mane, pane, crane, lane" from the rhyme family "ane" 


\subsection{Baseline 5: Personal Details (LSRW)}

Sample questions are as follows: "What is your name?", "Where do you live?", 'Are you a boy or a girl?", and "How old are you?". Children were asked to answer these questions and scores are recorded Table 6.

\section{f) Summary for Baseline Intervention: $Q 1$ to $Q 5$}

The summary of vocabulary test interventions on 30 children at an average age of 5 years 3 months urban children (K10 - K19) showed an increase in each baseline in the vocabulary (see Figure 4). This was because children had been exposed to rhythmic techniques during the learning process and were reflected in teachers' lesson plan notes.

Before undergoing intervention, the children learned all the phrases regarding themselves, age, and place of residence through songs. The result or scores recorded by teachers/researchers on K21 - K30, show that on average children have improved on their skills. Looking at the graph in Figure 4, assuming that

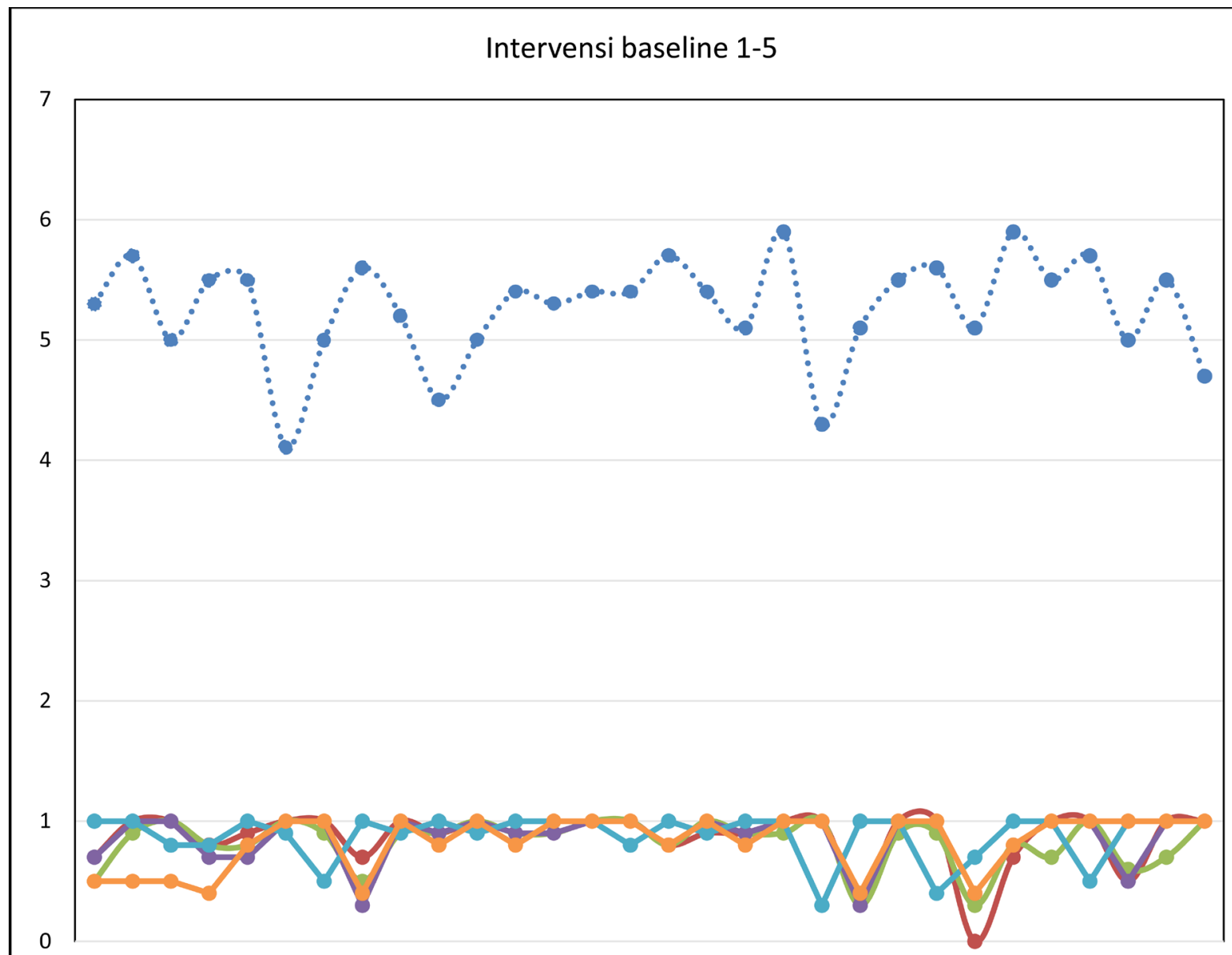

k1 k2 k3 k4 k5 k6 k7 k8 k9 k10k11k12k13k14k15k16k17k18k19k20k21k22 k23 k24k25k26k27k28k29k30

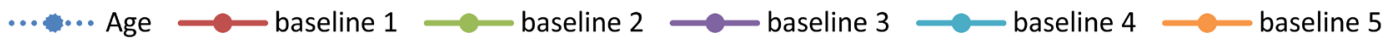

Note: k-child.

Figure 4. Summary of vocabulary changes bases $1-5$. 
the initial scores of children are "0", each line shows a gap from origin except for very few cases where scores hardly change even after intervention. This kind of case should be referred to experts from the special education needs area for further examinations; or teachers could try any other way to improve the rhythmic technique itself. These findings are parallel to the previous observations that children tend to master the new vocabulary when emphasis was given to the phrase during rhythmic techniques on induction sets, developments and even plenary.

\section{Conclusion}

Rhythmic technique is one of the inspirational approaches of learning by Reggio Emilia Approach (REA). REA aims to provide space for children to interact naturally, giving them the opportunity to highlight talents and feelings as well as to nurture creativity that contributes to the cognitive development of children (Moss, 2010, 2019). Basically, teachers need to be skilled to analyse the content of lessons that they want to convey and compose the lyrics according to the topic, the environment, or the ability of the child. Usually, children are quiet because he/she wants to interact with others in the way of communication he/she knows; the rhythmic method is an approach that could stimulate the mind and create multilateral interactions among children if they learn in group (Franco et al., 2017).

From the findings, we can conclude that rhythmic techniques are of useful tools to be applied in TLf process; but the issue remains whether teachers are prepared to spend time preparing the activities or not? This is mainly because i) teachers could be busy preparing worksheet and paper-and-pencil test; ii) teachers are not properly-trained or not familiar with the techniques; iii) parents/family may be resisting the singing/dancing activities because they are not academic enough for their kids, and finally iv) equipment and materials are not available or accessible to teachers even if they want to practice the more sensory-friendly method. We hope that the data could give a glimpse of hope for practitioner-researchers who are interested in trying out other than paper-and-pencil method. This study happened in government preschools i.e. Ministry of Education and therefore, we believe that implementation of these techniques could be carried out despite the rigid timetable of subjects to be taught in the scheduling, by applying at micro-scale level, for example, doing it 10 - 15 minutes during each slot of "subjects" like singing while learning science; dancing while learning language, etc.

Among the sensory skills that work during the rhythmic method are aural (listening skill through singing), physical (respiratory control and vocal mechanisms) and verbal (song lyrics comprehension, vocabulary, and language mastery). Therefore, the rhythmic techniques applied towards the children's learning can enhance vocabulary musically, train them to make a presentation with confidence, help them work together in groups and allow them to be courageous to communicate confidently. 


\section{Acknowledgements}

Appreciation for the cooperation by teachers at Ministry of education preschool centers for kindly allowing us to record their activities during data collection.

\section{Conflicts of Interest}

The authors declare no conflicts of interest regarding the publication of this paper.

\section{References}

Ashari, Z. M., Kosnin, A. M., \& Jiar., Y. K. (2013). The Effectiveness of Learning through Play Module on the Understanding of Number Concept among Preschool Children. Journal of Education and Practice, 4, 198-205.

Bahri, N. F., \& Yunus, F. (2018). The Fourth Industrial Revolution: Redesigning Education. ICGE VI.

Barrouillet, P. (2015). Theories of Cognitive Development: From Piaget to Today. Developmental Review, 38, 1-12. https://doi.org/10.1016/j.dr.2015.07.004

Bond, V. L. (2015). Sounds to Share: The State of Music Education in Three Reggio Emilia-Inspired North American Preschools. Journal of Research in Music Education, 62, 462-484. https://doi.org/10.1177/0022429414555017

Bredekamp, S. (2014). Effective Practices in Early Childhood Education: Building a Foundation. Boston: Pearson.

Buyong, N., \& Othman, N. (2018). Pelaksanaan Pengajaran dan Pembelajaran dalam Program Sekolah dalam Hospital. Jurnal Pendidikan Malaysia, 43, 11-16. https://doi.org/10.17576/JPEN-2018-43.01-02

Colwell, J., \& Enderson, M. C. (2016). When I Hear Literacy: Using Pre-Service Teachers' Perceptions of Mathematical Literacy to Inform Program Changes in Teacher Education. Teaching and Teacher Education, 53, 63-74.

https://doi.org/10.1016/j.tate.2015.11.001

Connors, A. (2014). How Music Sets the Tone for Learning. Teaching Young Children, 7, 21-23.

Coople, C. \& Bredekamp, S. (2009). Developmentally Appropriate Practice in Early Childhood Programs Serving Children from Birth through Age 8 (3rd Ed.) Washington DC: National Association for the Education of Young Children.

Dutton, S. E. (2015). Education in Rhythm and by Rhythm: Exploring Holistic Experiences in Dalcroze Pedagogy. ProQuest Dissertations and Theses.

Erneling, C. E. (2014). The Importance of Jean Piaget. Philosophy of the Social Sciences, $44,522-535$.

Franco, F., Chew, M., \& Swaine, J. S. (2017). Preschoolers' Attribution of Affect to Music: A Comparison between Vocal and Instrumental Performance. Psychology of Music, 45, 131-149. https://doi.org/10.1177/0305735616652954

Guignard, J.-B., \& Chomsky, N. (2011). Beyond Linguistic Wars: An Interview with Noam Chomsky. Intellectica, 56, 21-27.

Hale, L., Berger, L. M., LeBourgeois, M. K., \& Brooks-Gunn, J. (2011). A Longitudinal Study of Preschoolers' Language-Based Bedtime Routines, Sleep Duration, and Well-Being. Journal of Family Psychology, 25, 423-433. https://doi.org/10.1037/a0023564

Hamidin, N. M., Md Isa, S. N., Rahman, A. A., \& Hamdi, I. (2017). Pendidikan Awal Kanak-Kanak (Pakk) Di Malaysia: Kajian Literatur. Persidangan Antarabangsa Sains 
Sosial \& Kemanusiaan, Vol. 1, Bangi, 26-27 April 2017.

Holzman, L. (2013). Lev Vygotsky: Revolutionary Scientist, Classic Edition. Hove: Psychology Press.

Horn, E. M. (2003). Book Review: Assessment, Evaluation, and Programming System (AEPSTM) for Infants and Children, Second Edition Diane Bricker (Ed.), Baltimore: Paul H. Brookes, 2002. Complete AEPS (2nd ed.): Administration Guide (336 pp.), Test for Birth to Three Years and Three to Six Years (304 pp.), Curriculum for Birth to Three Years (512 pp.), and Curriculum for Three to Six Years (352 pp.), \$205.00. Topics in Early Childhood Special Education, 23, 41-42.

https://doi.org/10.1177/027112140302300105

Jawaid, A. (2014). Benchmarking in TESOL: A Study of the Malaysia Education Blueprint 2013. English Language Teaching, 7, 23-38. https://doi.org/10.5539/elt.v7n8p23

Jazira Najua, M. Y. (2016). Aplikasi Teknik nyanyan dalam pengajaran suku kata Bahasa Melayu-satu kajian tindakan bagi kanak-kanak berumur 3-6 tahun. Unpublished Thesis. Bangi: UKM.

Jones, J. D. (2018). Scaffolding the Dalcroze Approach. General Music Today, 32, 5-12. https://doi.org/10.1177/1048371318770821

Karabulut, A., \& Kesli Dollar, Y. (2016). The Effects of Presenting Different Types of Vocabulary Clusters on Very Young Learners' Foreign Language Learning. Education 3-13, 44, 255-268.

Kementerian Pendidikan Malaysia (KPM) (2017). Manual Pengurusan Data LINUS Pendidikan Khas-Sekolah Rendah.

https://www.moe.gov.my/en/muat-turun/pendidikankhas/program-pemulihan-khas/m uat-turun-linus-pendidikan-khas-mbk-sekolah-rendah

Krämer, S., \& Bredekamp, H. (2013). Culture, Technology, Cultural Techniques-Moving beyond Text. Theory, Culture \& Society, 30, 20-29.

https://doi.org/10.1177/0263276413496287

Lestari, I., \& Ratnaningsih, T. (2016). The Effects of Modified Games on the Development of Gross Motor Skill in Preschoolers. International Journal of Evaluation and Research in Education, 5, 216-220. https://doi.org/10.11591/ijere.v5i3.4542

Mac Naughton, G. \& Williams, G. (2009). Teaching Young Children: Choices in Theory and Practice. Maidenhead: Open University Press.

Ministry of Education Malaysia (2013). Malaysia Education Blueprint 2013-2025. https://www.moe.gov.my/en/dasarmenu/pelan-pembangunan-pendidikan-2013-2025

Moss, P. (2010). English as a Problem Language. Contemporary Issues in Early Childhood, 11, 432-434. https://doi.org/10.2304/ciec.2010.11.4.432

Moss, P. (2019). Alternative Narratives in Early Childhood: An Introduction for Students and Practitioners. Oxford: Routledge. https://doi.org/10.4324/9781315265247

Nakata, T., \& Trehub, S. E. (2011). Expressive Timing and Dynamics in Infant Directed and Non-Infant-Directed Singing. Psychomusicology: Music, Mind \& Brain, 21, 45-53. https://doi.org/10.1037/h0094003

Nordin, N., \& Norman, H. (2017). Mapping the Fourth Industrial Revolution Global Transformations on 21st Century Education. ICERD, 2, 8.

Phoon, H. S., \& Abdullah, A. C. (2014). Oral Vocabulary as a Predictor of English Language Proficiency among Malaysian Chinese Preschool Children. 3L: Language, Linguistics, Literature, 20, 143-156. https://doi.org/10.17576/3L-2014-2001-11

Rajan, R. S. (2013). I’ve Got Rhythm! Fostering Child-Centered Musical Activities for Preschoolers. General Music Today (Online), 26, 9-13. 
https://doi.org/10.1177/1048371312447937

Ruksenas, J. (2012). The Benefits of Music Classes for Preschoolers: The ABC of Do Re Mi. Bulletin of the International Kodály Society, 37, 19-26. http://search.proquest.com.proxy.library.vanderbilt.edu/docview/1348075049

Schwartzberg, E. T., \& Silverman, M. J. (2014). Music Therapy Song Repertoire for Children with Autism Spectrum Disorder: A Descriptive Analysis by Treatment Areas, Song Types, and Presentation Styles. Arts in Psychotherapy, 41, 240-249. https://doi.org/10.1016/j.aip.2014.03.007

Shenfield, T., Trehub, S. E., \& Nakata, T. (2003). Maternal Singing Modulates Infant Arousal. Psychology of Music, 31, 365-375. https://doi.org/10.1177/03057356030314002

Stone, J. E. (2012). A Vygotskian Commentary on the Reggio Emilia Approach. Contemporary Issues in Early Childhood, 13, 276-289. https://doi.org/10.2304/ciec.2012.13.4.276

Strait, D. L., Parbery-Clark, A., O’Connell, S., \& Kraus, N. (2013). Biological Impact of Preschool Music Classes on Processing Speech in Noise. Developmental Cognitive Neuroscience, 6, 51-60. https://doi.org/10.1016/j.dcn.2013.06.003

Trainor, L. J., \& Cirelli, L. (2015). Rhythm and Interpersonal Synchrony in Early Social Development. Annals of the New York Academy of Sciences, 1337, 45-52.

https://doi.org/10.1111/nyas.12649

Welch, G. F. (2012). Singing and Vocal Development. In G. E. McPherson (Ed.), The Child as Musician: A Handbook of Musical Development (pp. 311-329). Oxford: Oxford University Press.

Yunus, F. (2017). Changing Curriculum Practice in Early Childhood Education Setting: An Action Research to Enhance Authentic Assessment. Advances in Social Sciences Research Journal, 4, 48-61. https://doi.org/10.14738/assrj.411.3267 